\title{
The virtual shopping basket versus the shopping trolley: An exploratory investigation of consumers' experience
}

\author{
Surette van Staden and DJ F Maree
}

\section{OPSOMMING}

Die doel van hierdie studie was om verbruikers se gedagtes en gevoelens oor sowel die aanlyn- as die tradisionele inkopie-omgewing te beskryf. 'n Homogene steekproef van tien vroulike respondente het aan hierdie kwalitatiewe studie deelgeneem, en hulle ervarings is by wyse van die Zaltman Metaphoric Elicitation Technique (ZMET) ondersoek. Daar is bevind dat diegene wat op die tradisionele manier inkopies doen, hulle gedagtes en gevoelens om twee metafore organiseer, naamlik "inkopies doen as 'n vorm van ontspanning" en "inkopies doen as 'n vorm van werk". Diegene wat aanlyn inkopies doen, het aangedui dat dié manier van inkopies doen beskou word as "'n gerief" én as "'n moeilik deurgrondbare konsep". Naas hierdie vier temas het daar twee ondersteunende dimensies na vore gekom, naamlik inkopies doen vir dinge wat "noodsaaklik is om te hê" en inkopies doen vir dinge wat "lekker is om te hê". 'n Konseptuele raamwerk wat op hierdie temas en dimensies gebaseer is, is opgestel. Hierdie raamwerk was nuttig om die gevoelens en ervarings wat deur die een inkopie-omgewing opgeroep is, te vergelyk met dié wat deur die ander inkopie-omgewing opgeroep is; asook om die wisselwerking, ooreenkomste en verskille met betrekking tot ervarings binne die twee omgewings aan te dui.

\section{- Ms S van Staden}

Centre for Evaluation and Assessment

Faculty of Education

University of Pretoria

\section{- Prof David JF Maree}

Department Psychology

University of Pretoria

\section{INTRODUCTION}

While most people regard shopping as part of their daily routines, it is an activity that is likely to change and has already changed dramatically through the use of technology. With literature swarming with words such as 'Internet revolution', 'e-tailing' and 'Webolution', the role of technology for something as mundane as shopping is confirmed. It also confirms that while the world needs shopping services, it does not necessarily need traditional bricks and mortar shops anymore. Feather (2001:7) quotes Bill Gates, chairman of Microsoft, who summarised it aptly: "We are crossing a technology threshold that will forever change the way we learn, work, socialise and shop. It will affect all of us in ways far more pervasive than most people recognise."

In this changing environment an understanding of consumer behaviour and patterns is crucial to those involved in marketing, advertising and retailing; whether they operate in a conventional or nonconventional manner. Research in the area of differences in these environments is growing, and this study is a contribution to the exploration of those differences, albeit in a specific manner; i.e. we attempt a qualitative description of the consumer's experience of the online environment on the one hand, and of the traditional environment on the other.

While the era of virtual commerce has begun in North America and Europe where almost every business, home and public institution will have Internet connectivity within the next five to ten years, how far have we come with this development in South Africa? According to Langa (1999:3) the growth of Internet usage in South Africa has been phenomenal. What started as a small, but active, Internet community ten years ago within the academic sphere (Jensen, 1997), grew to an estimated 1,2 million users from a population of over 40 million people by the end of 1998 . It was estimated to reach 4 million in 2003 (cf. North et al, 2003). This still represents only the average user base of a medium sized American Internet Service Provider (ISP) and reflects less than $1 \%$ of worldwide Internet connectivity (Langa, 1999:4).

Demographic characteristics of the South African online shopper

According to Catt (2000:5), all indications are that online retailing is growing in South Africa. Bidoli $(2000: 2)$ supports this by stating that the number of electronic commerce transactions for the 1999 Christ- 
mas period showed a $607 \%$ year-on-year increase. Despite this growth, not only consumers, but also retailers remain circumspect about the prospects of ecommerce in South Africa. Bidoli (2000:3) feels that for many consumers the idea of firing up Windows to do a bit of shopping remains unpleasant, seeing that a trip to the local mall, shopping centre or flea market remains a social experience. However, with trusted retailers (such as Woolworths, Edgars and Pick 'n Pay) going online (cf. Catt, 2000:5), South African consumers are likely to become more confident in effecting purchases online.

The profile of the average South African online shopper resembles that of their overseas counterparts. While men continue to make up the vast majority of online shoppers (60\% versus $40 \%$ female) according to What are South Africans buying online? (2000), the profile continues to evolve. Jayawardhena et al (2003) found that the tendency to buy online is influenced by gender and previous buying experiences, but the differences between males and females are decreasing. Although 35 appears to be the average age, the 18 to 24 -year-old bracket is showing the most rapid growth. Buyers with children (58\%) outweigh buyers without $(42 \%)$, while $59 \%$ of online shoppers are married or living with a partner.

Consumers often browse the Web without necessarily making a purchase. When examining the South African statistics this is clear, as $74 \%$ of Web users have never bought anything online. Only $34 \%$ of those who have ventured online have made purchases more than five times. According to What are South Africans buying online? (2000), these frequent buyers are more likely to be male, English speaking, resident in Gauteng, and computer professionals. South African Web users also seem to use the Internet mainly to search for information. During the course of 2000, their frustration with the slow speed of the Internet increased to such an extent that in November of 2000, $55 \%$ of users cited slow speeds as the major frustration keeping them from shopping online and the reason why they only used the Internet as a search tool. Online consumers in the Northern Hemisphere listed efficiency, ease of use and pleasure as their main reasons for shopping online. Reasons given by South African consumers are consistent with their overseas counterparts. According to Catt (2000:4), consumers here prefer online shopping because it saves time (64\%), affords them more convenient shopping hours (51\%), stores, malls and shopping centres are too crowded (42\%), and no driving (and its concomitant parking problem) is required (40\%).

Catt (2000:5) stated that by the end of 2000 , South African consumers were expected to shop in more categories on the Internet. Popular categories include books, CDs, computer hardware and software, ticket sales and Internet banking (cf. North et al, 2003). Bidoli (2000:3) adds sport and leisure equipment, flowers and wine to the list, and stated that the growth in electronic goods purchased showed that South Africans were prepared to buy higher value items across the Net.

\section{Psychological characteristics of the shopper}

In its emphasis on technology's potential as a marketing tool, it is therefore not surprising that existing literature seems to discuss extensively the role of companies, organisations and entrepreneurs, and their attempts to optimise virtual marketing strategies (for example Frost \& Strauss, 1997:150-161, Helander \& Khalid, 2000, McCarthy, 1999:25-36, Peterson, 1997:7-15 and Wingham, 1998:5-46). Other sources (for example Branwyn, 1995:3-46, Cope, 1996:13-34, Rohner, 1998:3-27 and Sterne, 1997:25-43) offer step-by-step guidelines for utilising the Internet as a marketing tool, offering advice on how to assure customer returns, whilst also warning against potential pitfalls unique to the virtual environment.

Whilst the usefulness and necessity of literature of this nature cannot be denied, consumer experiences seem to get lost in the process. With a seemingly one-sided focus on the application possibilities of the Internet, the consumer as an individual with thoughts, feelings and experiences tends to fade into the background. For this reason, the current study investigated the consumer's cognitive and emotional experiences of the different shopping environments in order to supplement the understanding of recent studies that focused on subjective experience.

Bhatnagar and Ghose (2004) warn against over utilising the demographics of online shoppers. Research which combines demographics and the shopper's views and perceptions of the medium used is much more valuable. For instance, a number of issues are coming to the fore, such as the prospective and current online shopper's perception of the risks associated with Internet usage (cf. North et al, 2003). Another issue is that online shoppers are more concerned with security than finding the lowest prices (Bhatnagar \& Ghose, 2004), although one would expect pricing would play a role as with conventional shopping modes. This indicates that perceptions and motivations at an intrapsychic level could function differently in online environments than in traditional shopping environments. The focus on the individual and intrapsychic factors does not deny the plea to recognise that the shopper carries with him/her a social, and larger economic context that influences decisions to participate in e-commerce (Geurin, 2003). A fuller understanding of the individual level of consumer functioning is assumed to interact with broader social and other contexts.

A move in the direction of exploring the subjective factors is indicated by studies that investigate the role of trust and risk perceptions in consumers' involvement in online shopping (Corbitt et al, 2003). The ability of a client to form a relationship of trust is crucial for successful e-commerce. Similarly, the alleviation of negative perceptions and the implementation of strategies that reduce risk, such as money back guarantees, partnerships with well-known companies, and positive feedback from other users contribute to continuous participation in e-commerce (Corbitt et al, 2003). Consumers' perceptions of risk, ease of online 
transactions and their perception of the usefulness of online transactions influence online behaviour but it is also moderated by transaction targets such as buying products or services (Lui \& Wei, 2003).

This study is aimed at describing shoppers' experiences of actual and virtual shopping with the emphasis on subjective experience. Subjective experience refers to cognitive and emotional experience; for example, a person can provide rational or emotive reasons for preferring a particular shopping environment. Although the two broad cognitive/affective models for consumer behaviour (see below) explain the motivation for preferences and choices differently (cf. Malhotra, 2005, Lin, 2004), we do not aim to explicate the relationship between cognitive and emotional factors in this study and merely assume that they are important, in contrast with studies which negate their importance.

The cognitive-primacy model indicates that consumer behaviour is based upon the rational decisions of consumers. Affective states follow only after decisions, based on adequate information, are made (cf. Lazarus, 1982). In contrast, Zajonc's (2001) affectiveprimacy model holds that emotion can be evoked without prior cognition; there is even physiological evidence that emotions can be evoked separately from cognitive activity. The primacy of emotion has enormous implications for consumer behaviour and evidence that emotions play a greater motivational role than cognition has been found in a number of studies (cf. Chebat \& Michon, 2003, Ratner \& Herbst, 2005, Shiv \& Fedorikhin, 2002).

Ratner and Herbst (2005) for instance, found that when rational choices have negative outcomes, then the negative emotions associated with that outcome tend to influence future decision-making behaviour; persons then choose other and less favourable options. Zaltman (2003:20) also leans towards the affective-primacy direction in the sense that mental activity depends on social, psychological and biological process of which the consumer is usually not aware. However, the situation is probably not as simple as merely giving primacy to either cognition or emotion. Evidence was found for more complex interactions and relationships between cognition and emotion, and conceptual models were developed to accommodate these (cf. Agarwal \& Malhotra, 2005, Dubé et al, 2003).

\section{RESEARCH METHOD}

\section{The Zaltman Metaphoric Elicitation Technique (ZMET)}

For the purposes of this study, the Zaltman Metaphoric Elicitation Technique (ZMET) was used. As a qualitative data gathering technique, it is aimed at revealing the metaphors that organise and structure respondents' thoughts and feelings about a topic. A number of assumptions underlie the technique, and all fundamentally assume that consumers' awareness of their own needs is so deeply embedded that it rarely surfaces. Pink (1998) refers to Zaltman in this regard, who said:

"A lot goes on in our minds that we are not aware of. Most of what influences what we say and do occurs below the level of awareness. That's why we need new techniques: to get at hidden knowledge - to get at what people don't know they know."

Therefore, basically the technique assumes that most social communication is non-verbal - this means that thoughts occur as images, and that metaphors are central to cognition. Zaltman (2000) believes that deep structures of thought are accessible and for that reason, thought, experience and emotion are connected.

ZMET works by drawing out metaphors from customers by asking them to spend a few weeks thinking about how they would visually represent their experiences of a company, product or service. Respondents are asked a vague question, such as 'What are your thoughts and feelings about online shopping?' as was done in this case, and they are then requested to collect a minimum of 12 pictures or images from magazines that best convey their thoughts and feelings about the topic. After allowing respondents to spend a week or two completing the task by making a collage of the selected pictures, a personal interview is conducted of approximately two hours in duration. This guided interview takes the respondent through a number of steps, all of which are intended to elicit 'stories' about the images.

Olson and Zaltman (2000) describe the ZMET interview as a one-on-one discussion of approximately 2 hours in duration, as opposed to an average 'speaking time' in a focus group of approximately 10 to $12 \mathrm{~min}$ utes per respondent. Issues of reliability and validity of data are important considerations during the interview. For the purposes of collecting reliable data, it is necessary to try to ensure that all respondents interpret the questions consistently and can answer them as honestly as possible. Furthermore, the techniques described below allow for trustworthy results because respondents explain their views from multiple perspectives that let interpretations converge.

In terms of validity, it is necessary to ensure that questions and discussions adequately uncover the underlying feelings and perceptions by utilising the respondent's own choice of images and interpretation. The interviewer's interpretation is also checked against the respondent's interpretation (see below). For the purposes of this study, specific open-ended questions were initially asked as a basis for uncovering themes and ideas. Respondents' answers to these questions from the interview schedule served to further openended questioning and probing.

The ZMET interview employs several steps to surface and elucidate respondents' key thoughts and feelings.

Storytelling Olson and Zaltman (1999) refer to the first step as the storytelling step, as respondents are 
asked to 'tell the story behind each picture on the collage'. During this step, respondents describe how each picture conveys their thoughts and feelings about the topic. Olson and Zaltman (2000) are of the opinion that knowledge and memories often take the form of stories, which are rich sources of metaphors for experiences, thoughts and feelings.

Three probing techniques are used during this stage to explore why key ideas are relevant to respondents. Firstly, probes for basic elaboration are used as a form of reflection where the statements made by respondents are repeated in the form of questions; e.g. 'Running through a park?' Secondly, laddering techniques aim at identifying the ways in which respondents link ideas and concepts; e.g. 'When you think about the relationship between $X$ and $Y$, what images come to mind?' Thirdly, breaching is used as a probing technique in instances where respondents might show resistance (e.g. respondents who keep saying 'I don't know') or find it difficult to articulate their thoughts. An example of breaching would be to ask about the negative, or opposite, of an issue, or to inquire about consequences or antecedent factors.

Olson and Zaltman (2000) recommend that the storytelling step should be ended by asking respondents to describe the main theme of each image in a word or two, or to capture the overall theme of the collage with a fitting caption. This ensures that the interviewer's perception of image themes is in accordance with the respondent's description.

Missing images During this step, respondents describe images they were unable to obtain in picture format that would also convey their ideas. Describing 'missing' images is similar to the storytelling step, since respondents are asked to expand their thoughts and feelings as though the missing images were present.

Triad comparisons The triad task seeks to identify concepts and distinctions at a higher level (Olson \& Zaltman, 2000). The interviewer selects any three images, and the respondents indicate the similarities between the two, but indicate how the images differ from the third. According to Olson and Zaltman (1999), the triad step provides interviewers with the opportunity to explore concepts in depth if extensive probing and laddering was omitted during the storytelling phase. The triad step also offers possible additional insights, since the juxtaposition of images could stimulate new thoughts and feelings.

Metaphor probe (expanding the frame) By employing this step, respondents might offer new thoughts and feelings after manipulating the images (Olson \& Zaltman, 1999). This is accomplished by asking respondents to widen the frame of images in their mind's eye and to describe what else might enter the picture that reinforces the original idea. Respondents could also be asked to include themselves in the image and to elaborate on what they would be doing, thinking or feeling. Lastly, respondents may be asked to invite something or someone into the picture, or to create a chronology of pictures likely to have either preceded, or following, the focal image.

The interviewer selects images for discussion in the triad task as well as the metaphor probe. Although it might seem a random selection, Olson and Zaltman (1999) advise the interviewer to focus on images that might have surplus meaning for the respondent, images where the respondent had much to say about during storytelling, or images that visually lend themselves to expansion.

When attempting to uncover consumer experiences, the focus is on the associated thoughts and feelings pertaining to either of the shopping environments - in other words, how the virtual shopping environment impacts on the emotions and cognitive thought processes of the individual consumer as opposed to thoughts and feelings associated with the traditional methods of shopping. The emotional aspects of either of the shopping environments would include positive elements such as feelings of safety, excitement and satisfaction, or negative emotions such as tension, stress, annoyance, discomfort or impatience. Consumers' cognitive experiences could include awareness of products and services, motivation to buy products and services, contrasting and comparing the different shopping alternatives, and making decisions as to whether or not to buy. These emotional and cognitive aspects are revealed by the metaphors the participants use and the way they describe them.

\section{Selection and composition of respondents}

The reason for keeping the number of respondents low in a qualitative study of this nature is that of data saturation. It is expected that a large sample of respondents might lead to redundancy of data where similar ideas emerge from different respondents. Hence, a large sample of respondents does not necessarily reflect the richness of information, and therefore this sample was restricted to a limited number of respondents. The time demands of the technique regarding transcribing and interpreting data necessarily also limited the scope of this study.

The respondents that agreed to take part in this study were all white females between the ages of 25 and 35 residing in the greater Pretoria area. The consistently low numbers of females participating in online shopping (see discussion above) predisposed the investigation in the direction of probing the motivational factors in females. The respondents were divided into two groups, five of whom have never done any online shopping, with the remaining five having had considerable experience in buying groceries, books, flowers, clothing and music online. All the respondents are gainfully employed, with education levels that vary between senior certificates and tertiary degrees. None, however, had postgraduate qualifications. Eight respondents were married with children, while the remaining two were respectively single and divorced. 
Ethical considerations discounted the use of virtual commerce service-providing businesses due to the nature of the confidential information to which these businesses have access (e.g. credit card and telephone numbers). For this reason, a random sample could not be selected. Instead, the snowball technique had to be used, where access to one respondent who had online experience led to establishing contact with other potential respondents (Neuman, 1997:207)

\section{Analysis of the ZMET data}

Before undertaking the study, it was deemed appropriate to pilot test ZMET as a data gathering technique on volunteers. During pilot testing, problems could be identified not mentioned in the literature and which might have occurred during the data gathering stage. These problems were then attended to, or borne in mind before data gathering was undertaken.

A number of steps can be identified in the data analysis process; the first being the transcription of each individual interview. Each transcript was read to identify constructs (words, phrases and sentences used by respondents to articulate their thoughts and feelings) and re-read to identify the surface metaphors used. Surface metaphors refer to the spoken metaphors explicitly used and mentioned by respondents during each interview; for example, 'Shopping is a match that is burnt out.'

Based on these surface metaphors (or explicit metaphorical expressions), themes or conceptual metaphors were identified. These conceptual metaphors form themes that support, clarify and elaborate on the surface metaphors. Ideas, reasoning and experiences could be identified that support the surface metaphor. This list of themes was used as a basis to systematically code each transcription. Finally, the conceptual metaphors enabled the formulation of deeper metaphors. Zaltman (2000) refers to these as the organising framework for the system of concepts, and are the most fundamental categories of thought. Deep metaphors can be said to serve as the umbrella concept under which other concepts can be organised and categorised.

\section{RESULTS}

\section{Traditional shopping: introduction}

In order to provide a systematic discussion, findings relating to traditional shopping and online shopping will be presented separately. We will use the deep metaphors that were identified, namely shopping as play and shopping as work, as a framework for presenting and discussing respondents' thoughts and feelings related to traditional ways of shopping. It should be remembered that the deep metaphors were identified only after extensive analysis. We start with the deep metaphors, mainly to structure the results.

\section{Traditional shopping as play}

The deep metaphor of 'shopping as play' refers to respondent's experiences of traditional shopping as a social activity, aimed mainly at relaxation and spending time with loved ones. Five different conceptual metaphors, or themes, each with their own surface metaphors, explanations and experiences, can be categorised in this context:

- Shopping is a health enhancing activity.

- Shopping implies relaxation and calmness.

- Shopping brings joy and excitement.

- Shopping means togetherness with friends, family and loved ones.

- Shopping is a means of obtaining goals.

The three most salient themes will be discussed below, and the perceptions and feelings expressed will be italicised for the benefit of the reader.

Shopping as a health enhancing activity Some respondents described shopping as a healthenhancing activity, or as having healing properties, and used the metaphor of shopping as an energyboosting vitamin. Not only did it lead to more positive emotions (such as joy and self-satisfaction) and enhanced levels of energy, it was also used as a means of escaping everyday frustrations, bad moods and shifting the focus from the nagging demands of everyday life. Shopping's healing capacities were also described in terms of physical activity, or as exercise; shopping centres and malls provided one respondent with the opportunity to walk around and be physically active.

Images used by respondents to convey their feelings of shopping as a form of exercise and a source of 'vitamins' and energy ranged from pictures of bottles of vitamins to pictures of women doing strenuous exercise. Images of toothpaste also appeared, indicating that shopping keeps one healthy in the same way that toothpaste keeps one's teeth healthy.

\section{Shopping implies relaxation and calmness}

Metaphors pertaining to shopping as a relaxing and calming activity were used in two ways. Some respondents indicated that shopping had a relaxing and calming effect on them, much the same way as lying resting on a bed. Other respondents indicated that by using images of beds, it is implied that relaxation and calmness would follow a shopping trip. One respondent used the colour blue to indicate how she associated shopping with relaxation and calmness.

Another image used to convey feelings of relaxation and calmness flowed from shopping as a family event, such as an entire family shopping together with all in a seemingly relaxed mood. This verbatim response by a respondent illustrates the value shopping has as a potential opportunity for the family to be together:

"Ek dink dis iets wat ' $n$ mens kan saam doen, ons doen nogal min dinge saam - my man werk langer ure as ek en ons doen min goed as ` $n$ familie saam. En 
ek meen as 'n mens saam is, kan jy altyd ná die tyd iets gaan drink iewers en dit spesiaal maak." ${ }^{1}$

As opposed to images of happy families shopping together, other images included feelings of privacy and time alone. One respondent chose an image of a quiet, countryside shop to emphasise the importance of relaxation, calmness and time alone when shopping. A feeling of satisfaction followed these shopping experiences.

\section{Shopping brings joy and excitement Many re- spondents described shopping as a joyous activity, not only in terms of the joy it brought to them, but that it can also be extended to others. Some respondents used images of couples walking together or holding hands. Images of chocolates, sweets and candy were used to convey the idea of shopping as a source of joy to the respondents personally, as purchasing physical products or services implied a form of personal needs satisfaction.}

The idea of joy, however, was also extended beyond experiences of those near and dear to the respondents. One respondent used an image of a little girl holding a chocolate cake in her lap to convey the joy she saw on others' faces when she bought them unexpected treats or gifts. Other images were used to convey the same idea. One respondent admitted that she didn't necessarily need to shop for herself to feel good, but that shopping for someone else also made her feel happy. In addition, the joy shopping brought seemed to extend beyond what was physically purchased and included feelings of joy when emotional energy was invested in purchases for significant others.

Shopping was also described as exciting. Respondents described their experiences of excitement in terms of the colours seen in flowers, and this was conceptualised in terms of viewing many different and interesting people while shopping. At the same time, respondents were intrigued and excited by new and strange products and the variety of packaging for the various products.

\section{Traditional shopping as work}

The second deep metaphor of 'shopping as work' refers to respondents' experiences of shopping as something that has to be done but is a tedious chore characterised by frustrations and limitations. Under the umbrella concept of 'shopping as work', six different themes were identified along with various surface metaphors used to elaborate on and explain respondents' thoughts and feelings:

- Shopping would be more enjoyable if there were less people around.

\footnotetext{
1 "I think it is something that one can do together, we do not do a lot of things together - my husband works longer hours than I do and we do not do things as a family. And I think that when you're together then you can always go and drink something somewhere and make it special."
}

- Shopping resembles the experience of physical pain.

- Shopping leads to exhaustion.

- Shopping is like going to work.

- Shopping is addictive.

- Shopping is a frustrating activity.

As in the previous section, only the most salient themes will be described.

Shopping would be more enjoyable if there were less people This theme reflects some respondents' ideal shopping situation whilst others had very unfavourable experiences of shopping and thus stated this explicitly in their surface metaphors. In illustrating the ideal of less crowds and more space to move about freely, one respondent used the image of an empty staircase to portray what she would prefer to be a more acceptable shopping environment. The empty staircase led to a large, empty room, illustrating the absence of other people. Another respondent used the image of a 24-hour shop to convey the ideal situation of being able to shop at night when few customers were present. This respondent seemed to highlight the presence of many other people as a disturbance in her shopping experience.

Shopping resembles the experience of physical pain Describing shopping as a physically painful exercise elucidates the effect of discomfort with the social dimension as emphasised above. One respondent described the feeling in terms of being squeezed tight by a shifting spanner. This resembled feelings of being in overcrowded shopping centres where personal space and room to move around comfortably is limited, especially in situations with long queues of customers, crowded alleys and passages, and not being able to make purchases quickly and effectively. In addition, a number of respondents referred to images of headaches and headache tablets to represent their shopping experiences. Images of Bioplus represented shopping as an energy sapping activity requiring supplements.

Images of shoes and illustrations of feet were used to convey another surface metaphor of the pain of shopping. Thus headaches and sore feet indicate experiences of physical and emotional pain such as frustration and agony.

Shopping leads to exhaustion In a previous paragraph shopping was likened to an energy sapping activity for which vitamin supplements were needed. This theme could be extended in the form of other metaphors used to convey feelings of exhaustion. Therefore, it was mentioned that shopping makes one feel exhausted in the same way as one's money is exhausted at the end of a shopping trip. This simile was illustrated by an image of a man turning his empty pockets inside out, emphasising the exhaustion of monetary resources resembling the exhaustion of physical energy after a shopping trip. The feeling of being a 'burnt-out match' after shopping was another image used. 
Shopping is like going to work For some respondents, describing shopping as a form of work occurred in one of two ways. On the one hand, some respondents described shopping as an activity that resembled going to work everyday. Just like their daily work situations, shopping implied some form of planning in terms of where to go and what to purchase, and some form of time management.

On the other hand, shopping itself was regarded as a form of work. Many respondents described their typical activities involved when shopping; planning where to go, finding time to shop after work, coping with tired children that often had to accompany them, loading and unloading the car, unpacking purchased goods, and storing them in their proper places. One respondent used an image in her collage of a professionally dressed woman placing a trolley load of purchased goods into her car. This image illustrated shopping as a form of work; not only in the woman's dress, but in the physical activity of unpacking the car.

\section{Additional traditional shopping themes}

Some additional, but supporting, surface metaphors were identified. Shopping was referred to as a social activity, where the purchase of gifts, self-indulgent products or services, visits to restaurants and coffee shops, and entertainment added to the experience of shopping as a social activity. This dimension typifies 'nice to have' shopping aspects and closely resembled the experiences, thoughts and feelings described by the deep metaphor of 'shopping as play'. Closely related to the deep metaphor of shopping as work, and reflecting a 'must have' dimension, respondents described shopping as a chore. Household and home improvement products have to be purchased. Monthly grocery shopping is included in this type of shopping activity. While 'must have' shopping could be associated with more careful planning using a taskoriented approach, the 'nice to have' shopping was aimed at relaxation, spending time with significant others, and browsing in shops. This implied fewer constraints on time and a less task-oriented approach.

The idea of shopping as a social activity was emphasised in a number of ways. Respondents preferred to take along close family members, or at the least, a very good friend on their shopping trips. While some respondents indicated that they would prefer their husbands to shop with them, others included their siblings or their best friends. In this way, a shopping trip created opportunities for time to be spent together in a relaxing atmosphere. The reasoning behind taking siblings or best friends along seemed to pertain to a longstanding relationship where similar interests, likes and dislikes are shared. When asked what it would mean to take someone along who had little interest in shopping or had different interests, one respondent indicated that she would opt to shop alone due to the frustration such a partner would create.

In terms of describing the main limitations to shopping, most respondents referred to the limits set by time and money. By not having enough money, most respondents related their feelings of frustration upon realising that satisfying their needs or wants had to be delayed. Time was indicated as a major constraint, seeing that shopping was often an activity to be done after work before stores closed for business at the end of each day. Time also seemed to be experienced as a constraint when 'must have' shopping was required. Extended shopping hours did not seem to make a difference, as household responsibilities (such as attending to children and preparing supper) kept most respondents from shopping later in the evening. For this reason, most respondents set time aside over the weekends to shop instead of rushing to do it after work. When asked how unlimited amounts of time would hypothetically influence their shopping experiences, many respondents indicated that it would turn their shopping into more of a social activity, even when 'must have' shopping was needed.

\section{Online shopping: Introduction}

Having discussed the deep metaphors, surface metaphors and supporting themes with regards to traditional shopping in the previous section, the following section will concentrate on respondents' thoughts and feelings with regard to the online shopping environment. Again, as in the case of traditional shopping, two deep metaphors regarding online shopping could be identified. These deep metaphors seem to summarise respondents' predominant opinions of online shopping. Firstly, online shopping is described as a convenience, and secondly as an unfathomable concept.

\section{Online shopping is a convenience}

The deep metaphor of convenience seems to organise and structure respondents' thoughts and feelings regarding the online shopping in a predominant way. The following section will elaborate on the surface metaphors and related themes that support the idea of online shopping as a convenience. Included themes are:

- Online shopping is a comfort.

- Online shopping means savings.

- Online shopping implies progression.

Online shopping is comfort In describing online shopping as comfort, respondents used metaphors relating to fast food and hi-tech appliances. By using an image of a slice of pizza, one respondent described online shopping as a comfort in much the same way fast food is regarded as a comfort and a convenience. The idea of a cellular telephone was used to describe how the introduction of such technology has changed many lives; it is convenient to use and at hand when needed. Images of a cup of coffee standing next to a computer keyboard illustrated the fact that a respondent could shop in a relaxed environment and in her own personal space. This particular respondent reported that the effect online shopping has had on her life is such that she cannot imagine what her life was like before the use of online facilities. Another respondent said that as part of her daily rou- 
tine she cooked food in a slow cooker so that by the time she went home after work in the afternoon the food would be ready for supper. She related how online shopping did much the same for her as the slow cooker in terms of products and services being provided with very little effort, and on time when needed.

Online shopping means savings Respondents seemed to perceive online shopping as a money saving device. Illustrated by an image of a treasure chest filled with money, one respondent reported that online shopping was equivalent to saving money. It allowed her to spend her money more wisely and with care seeing that online shopping provided information to make price comparisons easily without having to go to extra, time consuming trouble. In the traditional shopping environment (walking from one shop to the next), she often omitted the activity of price comparisons altogether. Another way in which online shopping was perceived as a money saving device was the fact that unlike traditional shopping, one's attention never wandered to new or appealing products which one had no intention of buying in the first place. The absence of products displayed at counters in the online environment was used as an example of how money was saved by not being exposed to this temptation.

Online shopping implies progression The image of a stepladder was used to illustrate the progressive nature of using technology to shop. Progress in this sense did not refer to the use of technology per se, but rather how the use thereof reflected progress in the respondents' lives. One respondent related how years ago, she bought a washing machine, which was followed by a dishwasher, to save time and effort. The use of these devices reflected some progress in terms of her personal family life, since the time saved could now be spent otherwise. Wydra and Martin (1997:13) emphasise the benefits of online shopping by stating that an average online shopping trip takes 37 minutes per order; considerably less time than in comparison with traditional store visits.

\section{Online shopping as an unfathomable concept}

The second deep metaphor is that of online shopping as an unfathomable concept. It is described as an unimaginable and daunting phenomenon, the workings of which are still difficult to completely grasp or understand. Some respondents used explicit surface metaphors of wild animals to describe their thoughts and feelings of online shopping.

Online shopping was illustrated by an image of an elephant, thereby implying its enormity and power. The walking speed of an elephant was also used as a metaphor for the tardiness of local networks in providing Internet connectivity and accessibility. Another image used to illustrate the intimidating and frightful nature of online shopping is that of a lion. The reasoning behind this image was that similar to the lion's ability to instil fear, the online environment is intimidating. One respondent used the example of grocery shopping online - on her first attempt at buying gro- ceries online, a complete history of what she had bought over the last three months (in the form of a shopping list) appeared on the screen. This information was solely based on her credit card number although the previous purchases had been made in a store by means of her credit card! The idea of stores, companies and businesses having access to transaction details and exact purchasing information gave the online environment an eerie quality, experienced by some as intimidating and instilling anxiety and fear in others. In a previous section, the work of North et al (2003) and Bhatnagar and Ghose (2004) was mentioned regarding online shoppers' concern with security and the risks associated with the Internet. In this case, online shoppers seemed to be well informed about online security and did not allow the perception of risk or feelings of fear to keep them from utilising the Internet.

\section{Additional online shopping themes}

It has to be kept in mind that the online shopping respondents have had exposure to both kinds of shopping environments, unlike the traditional shopping respondents who only had knowledge and experience of the traditional environment. For this reason, the online shopping respondents described many of their experiences of online shopping in comparison with their experiences of the traditional environment, thereby pointing out and emphasising the perceived advantages of shopping online.

Although the online shopping respondents experienced the online environment very favourably, a number of disadvantages to online shopping were also mentioned. In terms of online shopping keeping one's attention focused on what needs to be bought, it also prevented one from being exposed to new products or services. Online shoppers pre-prepared a shopping list, which meant that products on promotion or new products were often ignored. One respondent admitted to never going to the trouble of looking at what was new or on offer since her shopping list contained everything she needed. The contrast between the two environments is again emphasised by importing the experience of the one environment into the other. However, experiences of two environments can also seem very similar even though the originating experience is unique to one environment. For example, a disadvantage of the online environment pertained to technical problems with Internet access and connections. One respondent described this problem as similar to that of a store being closed.

As was the case with traditional shoppers, online shopping responses can also be categorised according to the themes of 'shopping as work' or 'shopping as play'. Online shopping respondents also admitted to experiencing some shopping activities (e.g. grocery shopping within the 'must have' dimension) as a form of work, while others were considered a form of play, e.g. spending money on gifts and self-indulgent luxuries ('nice to have'). However, not all the online shopping respondents regarded shopping in a favourable light and they regarded any form of shopping to be a loathsome chore. 


\section{Differences between the perceptions of traditional and online shopping respondents}

Traditional shoppers indicated the unlikelihood of them ever engaging in online shopping. To them, online shopping provided a less appealing alternative, seeing that it occurred in isolation from others and affects the extent to which shopping can be regarded as a social activity. For one respondent in particular, online shopping lacked the excitement traditional shopping was able to create. Respondents also indicated that online shopping would diminish the amount of emotional energy they perceived as investing in buying gifts or treats for others - ordering a gift to be delivered the next day did not have the same appeal as making the effort to go shopping and delivering the gift in person. The dimension of 'nice to have' within the theme 'shopping as play' that describes the traditional environment is now explicitly carried into the online context. This clearly emphasises the inability of the online environment to accommodate certain emotive and cognitive aspects of the shopper.

This is further illustrated by carrying the aspect of the importance of touching, smelling and seeing products before making a purchase into the online shopping context. Its experiential importance, and the inability of the online context to accommodate it, is highlighted. This seemed to be especially true for clothing, new products that were still unfamiliar and not previously sampled, as well as fresh produce. This rule did not seem to apply to packaged, canned or bottled products that are familiar and remain the same in quantity and quality from one purchase to the next (e.g. household cleaners, canned food or toothpaste). Respondents admitted that even detailed pictures of products gave no indication of the quality or nature of such products, but actually made the products seem unappealing, unattractive and unappetising.

Shopping as play in the traditional environment had a social dimension, but there were those who used online shopping as a means to avoid going shopping entirely. To these respondents, shopping was never considered a social activity. Others used online facilities to avoid the drudgery of 'must have' shopping. To them, online shopping provided a preferred alternative to the type of shopping that could be regarded as work. However, these respondents still preferred the traditional environment when it came to the 'nice to have' items, in this way still utilising the traditional shopping environment when shopping had a social dimension.

The nature of the interaction between the experiences of shopping environments depends on the initial perspective of the shopper. Traditional shopping respondents indicated the inability to use senses of touch, smell and seeing objects in three-dimensions as a major disadvantage of the online environment. Online shopping respondents, however, did not share this view with regards to certain items. Online respondents admitted to the disadvantage of buying personal items such as clothes online. Aspects such as size, how well the garment fits, the quality of the fabric, as well as comfort seemed to prevent many respondents from buying these items online. However, in describing the purchase of fresh produce and other foods online, respondents described how trained staff employed at the different chain stores became their eyes and ears. These assistants not only selected fresh produce on behalf of the customer, but also used the information provided by sell-by dates as an additional source of assurance that products were freshly packaged.

\section{DISCUSSION AND CONCLUSION}

The differences in experiences of traditional and online shopping are demonstrated when the participants describe their preference for one environment and contrast it with the less preferred shopping environment. Two deep metaphors were identified for each shopping environment: 'shopping as play' and 'shopping as work' for the traditional environment, and shopping as 'convenience' and as something 'unfathomable' in the online environment. The deep metaphors, or basic themes, are supported by two additional dimensions aimed at describing the focus of shopping, namely shopping for 'must have' or 'nice to have' items.

The main aim of this study was to provide a description of shoppers' cognitive and emotional experiences of the two shopping environments. The benefit of viewing the descriptions in this way is that it focuses one's attention on the subjective nature of the shopper's experience. One need not at this stage to try to solve the difficult problem of the relationship between cognitive and emotional descriptions, but it is necessary to note that a subjective experience has both cognitive and emotional dimensions.

For the purpose of this discussion, descriptions on the cognitive level are taken as rational motivations indicating benefits or problems with a particular shopping environment. Emotional descriptions involve images and concepts referring to the emotions or sensations such as fears, likes/dislikes, and so on. The metaphors and supporting themes in the traditional environment are more emotive in contrast with the rational descriptions of the online environment. When characterising a description as either cognitive or emotive, one should remember that the use of metaphors which involves images - does not preclude such an image or metaphor from having rational content. For instance, 'shopping as work' implies negative feelings because it is experienced as a chore, but it also refers to the structured, planned and goal-directed nature of shopping, which is a description on the cognitive level.

It is interesting to note that even obvious goal-directed or benefit-enhancing perceptions of traditional shopping have emotional implications, or an emotional base. For example, on the one hand, shopping as a health-enhancing activity can be described in terms of its rational benefits, but it can also be described in terms of its emotional gains such as escaping frustration. On the other hand, even the emotive metaphor 
of online shopping as an 'unfathomable' concept with its reference to wild and fearful beasts, has a cognitive basis. Internet shopping has qualities and benefits that can be enumerated rationally such as having one's grocery list available despite the feelings of anxiousness associated with knowing that previous credit card transactions are available online.

Deep and surface metaphors in both shopping environments have emotive and cognitive content and reflect shoppers' experience. It seems as if the teleological dimensions, i.e. shopping for 'nice-to haves' and 'must-haves' can be roughly divided along emotional and rational lines. 'Nice-to-haves' appeal to the senses; purchases may be for pleasure, whilst 'musthaves' are aimed at purchasing goods that are logically required for 'survival'. Again, this simple distinction can be misleading because traditional shopping for 'must haves' can elicit strong emotional feelings (hating crowds or having no money) while the online shopper, using the medium to escape crowded shopping areas, can experience feelings of relief.

One valuable observation in the study was shoppers experiences and perceptions of how to deal with objects one would normally like to see, smell and touch. Clothing presents problems, even to the avid online shopper who will probably avoid buying such items. Products the traditional shopper prefers to buy in a shop present no problems to the online shopper who entrusts the activity of choosing fresh, quality items to assistants in the shop. The traditional shopper prefers to do this herself. Here a deeper aspect than likes or dislikes, needs satisfaction, or the argument for the convenience of online versus traditional shopping arises. The willingness to entrust others with decision-making about something as personal as something one normally would like to have control over (such as quality and freshness) can indicate a crucial differential characteristic between online and traditional shoppers. Probing the psychological significance of this difference can probably provide valuable insight into the mind of the shopper. For instance, if this difference holds between larger and more diverse groups of shoppers, then the recruitment of online shoppers can focus on convincing them that personal items can be bought online with success.

In sum, the study described the emotional and cognitive experiences of online and traditional shoppers. These experiences were interpreted within a multilevel framework of deep metaphors or themes and surface metaphors with two additional dimensions of shopping for 'must haves' and for 'nice to haves'. This interpretative structure is helpful in organising the experiences within the two environments, especially if the emotional and cognitive content of experiences is exposed. This particular focus is important because it moves away from non-personal surveys such as characteristics of products, consumer profiles and behaviour, to personal and subjective experiences that include rational and emotional dimensions.

The interpretative structure can be helpful to a number of stakeholders in order to understand the subjective experiences of shoppers in the various environments. Despite its small sample size, rich information was provided which can serve as the stimulus for larger studies. One can capitalise on, and explore, the interesting contrasts and interactions between different experiences.

An interesting aspect is the prominence of the 'shopping as play' and 'shopping as work' themes that seem to be reflected in the teleological dimensions of 'nice-to-have' and 'must have'. Because this study focused on women, it will be interesting to see if the same structure can be found in the male experience. One expects the social aspect to dominate in female shoppers' experiences, and the issue of shopping to please others and bring joy to others could explain why more males use the online shopping environment. In other words, do males use online shopping for 'must have' items and do so because it accommodates shopping as well as work? When combining these questions with demographic findings such as an increase in Christmas online sales (see previously mentioned examples), interesting factors can be uncovered in the subjective experiences of shoppers. Females prefer traditional shopping for buying gifts because it has a 'nice to have' social dimension. It also originates from deep subjective needs and is experienced in a specific way. One suspects that males shop online for gifts as a matter of convenience and not for its emotional experience, but this is a matter for empirical investigation.

This qualitative investigation opens up avenues for understanding and exploring shopping behaviour by means of the experience of the shopper. The qualitative technique and the eventual interpretative framework can supplement or stimulate research conducted by means of surveys and analyses of demographics.

\section{REFERENCES}

AGARWAL, J \& MALHOTRA, NK. 2005. An integrated model of attitude and affect: theoretical foundation and an empirical investigation. Journal of Business Research 58: 483-493.

BHATNAGAR, A \& GHOSE, S. 2004. A latent class segmentation analysis of e-shoppers. Journal of Business Research 57: 758-767.

BIDOLI, M. 2000. Click and pay. Available online. URL: http://www.fm.co.za/report.perq100/hinter.htm. Accessed 27 July 2001.

BRANWYN, G. 1995. Internet Roadside Attractions: Sites, Sounds and Scenes along the Information Superhighway. Chapel Hill. Ventana.

CATT, I. 2000. Internet news. Available online. URL: h t t p : / / w w w . it w e b.co.za/s e c tions / intern/0012070741.asp. Accessed 27 July 2001.

CHEBAT, JC \& MICHON, R. 2003. Impact of ambient odors on mall shoppers' emotions, cognition, and spending: a test of competitive causal theories. Journal of Business Research 56: 529-539.

COPE, N. 1996. Retail in the Digital Age. London. Bowerdean.

CORBITT, BJ, THANASANKIT, T \& YI, H. 2003. Trust 
and e-commerce: a study of consumer perceptions. Electronic Commerce Research and Applications 2:203-215.

DUBÉ, L, ERVELLON, MC \& JINGYUAN, H. 2003. Should consumer attitudes be reduced to their affective and cognitive bases? Validation of a hierarchical model. International Journal of Research in Marketing 20:259-272.

FEATHER, F. 2001. Future consumer.com. Toronto. Warwick.

FROST, RD \& STRAUSS, J. 1997. The Internet: A New Marketing Tool. New Jersey. Prentice Hall.

GUERIN, B. 2003. Putting a radical socialness into consumer behavior analysis. Journal of Economic Psychology 24:697-718.

HELANDER, MG \& KHALID, HM. 2000. Modelling the Consumer in Electronic Commerce. Applied Ergonomics 31(6):609-619.

JAYAWARDHENA, C, WRIGHT, LT \& MASTERSON, R. 2003. An investigation of online consumer purchasing. Qualitative Market Research: An International Journal 6(1):58-65.

JENSEN, M. 1997. Internet regulation and development in South Africa. Available online. URL: http:// www.wn.apc.org/africa. Accessed 24 July 2001.

LANGA, M. 1999. Regulation and the Internet - A South African regulator's perspective. Available online. URL: http://www.iba.org.za/internet.htm. Accessed 24 July 2001.

LAZARUS, RS. 1982. Thoughts on the relations between emotion and cognition. American Psychologist 46:352-367.

LIN, IY. 2004. Evaluating the servicescape: the effect of cognition and emotion. International Journal of Hospitality Management 23: 163-178.

LUI, X \& WEI, KK. 2003. An empirical study of product differences in consumers' E-commerce adoption behaviour. Electronic Commerce Research and Applications 2: 229-239.

MALHOTRA, NK. 2005. Attitude and affect: new frontiers of research in the $21^{\text {st }}$ century. Journal of Business Research 58:477-482.

MCCARTHY, J.L. 1999. Commerce in Cyberspace. Kenilworth. Ampersand.

NEUMAN, WL. 1997. Social research methods: Qualitative and quantitative approaches. Boston. Allyn and Bacon.
NORTH, EJ, MOSTERT, PG \& DU PLESSIS, PJ. 2003. Cybershopping: concerns of the South African consumer. Journal of Family Ecology and Consumer Services 31:58-66.

OLSON, J. \& ZALTMAN, G. 1999. ZMET Interviewer Guide. Unpublished personal document.

OLSON, J. \& ZALTMAN, G. 2000. Overview of the ZMET Research Process. Unpublished personal document.

PETERSON, RA. 1997. Electronic Marketing and the Consumer. Thousand Oaks. Sage.

PINK, DH. 1998. Metaphor marketing Available online.

URL: http://www/fastcompany.com/online/14/ Zaltman.html. Accessed 29 November 2000.

RATNER, RK \& HERBST, KC. 2005. When good decisions have bad outcomes: the impact of affect on switching behavior. Organizational Behavior and $\mathrm{Hu}$ man Decision Processes 96:23-37.

ROHNER, K. 1998. Marketing in the Cyber Age: The why, the what and the how. Chichester. Wiley.

SHIV, B \& FEDORIKHIN, A. 2002. Spontaneous versus controlled influences of stimulus-based affect on choice behavior. Organizational Behavior and Human Decision Processes 87(2):342-370.

STERNE, J. 1997. What makes people click: Advertising on the Web. Indianapolis. Ventana.

What are South Africans buying online? 2000. Pro SA Web User. Available online. URL: http:// www.Webcheck.co.za/library_buying.html. Accessed 17 January 2002.

WINGHAM, R. 1998. Net Benefit: Guaranteed Electronic Markets - The Ultimate Online Trade. London. MacMillan.

WYDRA, D \& MARTIN, S. 1997. Online versus in line: Research implications of online grocery shopping. Available online. URL: http://www.marconline.com/ knowledgecenter/wtpapers/wtpr2.html. Accessed 3 August 2001.

ZAJONC, RB. 2001. Mere exposure, a gateway to the subliminal. Current Directions in Psychological Science 10(6):224-228.

ZALTMAN, G. 2000. Consumer Researchers: Take a Hike! Journal of Consumer Research 26: 423-428.

ZALTMAN, G. 2003. How customers think: essential insights into the mind of the market. Boston. Harvard Business School Press. 